\title{
Redaktionelle Notiz
}

Die Kant-Gesellschaft e.V. lädt zum 5. Internationalen Kant-Kongreß ein, der vom 4. bis 8. April ${ }_{198} \mathrm{I}$ in Mainz abgehalten wird. Sein Thema ist: " 200 Jahre Kritik der reinen Vernunft." Es wird in vierzehn Sektionen historisch, systematisch und kritisch behandelt.

Anmeldungen an den Vorbereitenden Ausschuß, Prof. Dr. Gerhard Funke, Philosophisches Seminar der Universität Mainz, Saarstraße 21, 6500 Mainz. 